\title{
The Political Economy of Tariff Formation in Vietnam
}

\author{
${\text { YOON } \mathrm{HEO}^{* *} \text { AND TRAN N. KIEN }}^{* * *}$
}

Using a simultaneous equation model of tariffs and imports, this paper empirically investigates the determinants of tariff rates applied in Vietnam using two-digit ISIC data over the 2001-2006 period. This paper extends the findings of previous studies in several ways. First, there has been no study thus far conducted that has attempted to apply the endogenous theory of tariffs to explain tariff formation in developing countries, including Vietnam. Second, imports and trade protection are simultancously modeled using the two-stage least square estimator. Third, this study employed an up-to-date panel dataset that was recently made available in Vietnam, which allowed us to measure the dynamic interactions among trade flows, industry characteristics, and trade protection. The results of this paper showed that tariffs are frequently high in industries with a small number of firms, large employment size, low import penetration, low industry growth rate, and less capital stock. Therefore, the findings of our study on Vietnam provide further evidence favoring the theory of endogenous protection.

Keywords: Vietnam, Endogenous Protection, Political Economy, Tariff, Trade

An earlier version of the paper was presented at Sogang Research Series on International Affairs, GSIS, Sogang. Dec, 2010. The authors would like to thank the ISR reviewers for their constructive comments. This research was supported by 2010 Sogang University Special Research Grant.

* Corresponding Author, Professor, Graduate School of International Studies, Sogang University, Director, Institute of International and Area Studies, Korea; E-mail: hury@sogang.ac.kr

vice Dean, Faculcy of Post-Graduate Studies, Thai Nguyen University of Economics and Business Administration, Vietnam; E-mail: tnkien( $\alpha$ tueba.edu.vn 


\section{INTRODUCTION}

The conventional wisdom among economists has long been that, with some exceptions, free trade represents the optimal policy option for small open economies. However, this theory is rarely employed to explain trade protection in practice. Rather, trade protection is frequently justified by reference to domestic political economic considerations, wherein the policy makers adopt objectives other than aggregate welfare maximization. This means that trade protection may often prove politically efficient, even if it is economically inefficient. In an attempt to evaluate the prevalence and persistence of trade protection, a large body of work that departs from the notion of welfare-maximizing governments and rather emphasizes the political-economic determinants of policy has emerged in recent decades (Gawande and Krishna 2003). Therefore, the theory of endogenous protection has been developed in an effort to explain the interactions between politicians and interest groups in the processes of trade policy formulation. The theory of endogenous protection holds that, in response to increased import competition, domestic interest groups will intensify their lobbying activities for greater protection (Trefler 1993). Thus, increased import penetration will be followed by greater protection.

Vietnam is an interesting case with which to test the theory of endogenous protection, because it has experienced marked economic growth and structural changes over the past two decades. There are at least three reasons to believe that Vietnam's trade policies are endogenous in nature. First, Vietnam's government has adopted trade policies as a method of legitimizing its power and to attain public acceptance of its goals, which include economic growth and social equality. Vietnam's remarkable achievements in terms of poverty reduction, accompanied by high and sustained economic growth, have bolstered the government's legitimacy. Second, the sweeping reforms in Vietnam have inevitably created both winners and losers. To be sure, certain interest groups are believed to benefit from the government's export promotion policies, whereas others have had to seek governmental protection. Thus, failure to improve equality is likely to trigger social unrest and political instability. High unemployment and inflation might result from the rapid transformation of the economy via market-oriented reforms and privatization. Therefore, the government may have to take these factors into consideration when formulating trade policies, with an eye toward maintaining social equality and political stability. Third, a variety of interest groups have emerged and have achieved great financial and political power during the processes of economic restructuring, decentralization, and international economic integration. Thus, interest groups (principally SOEs and local enterprises) lobby authorities via persuasion and bargaining. As noted previously by Athukorala (2006), the increase in tariff bands derives from the introduction of fractional rates at the lower end, presumably reflecting the government's attempt to respond to lobbying 
pressure from importers of intermediate goods.

This paper attempts to identify endogenous factors that influence the formation of Vietnam's tariff rates at the sectoral level. The determinants of tariffs at the two-digit ISIC level are assessed empirically using generalized two-stage least squares estimations. The paper proceeds from the theoretical framework shown in Section 2. Section 3 discusses the model specification. Section 4 shows the empirical results and discussion. Our conclusions are provided in the final section.

\section{THEORETICAL FRAMEWORK}

The question as to what factors determine the tariff structure of a country has been the subject of a number of empirical studies since the 1970s. Early work on the endogenous protection theory can be found in the studies of Stigler (1971), Constantopoulos (1974), Pincus (1975), Peltzman (1976), Caves (1976), Brock and Magee (1978), and Ray (1981). Such endogenous theories generally argue that tariff rates are not exogenous in nature, but are rather determined endogenously by the relationship between various interest groups and politicians. Put another way, the structure of tariffs is endogenous, as its formation derives from motives that lie beyond the scope of pure economic efficiency. Therefore, the theory of endogenous protection has focused on the analysis of domestic variables to explain inter-industry differences in trade barriers.

Gawande and Krishna (2003) have surveyed empirical approaches in the study of the theory of endogenous protection, and have concluded that the literature has been somewhat less than successful. They determined that, in empirical exercises, inference has been generally confounded by the insufficiently precise and frequently promiscuous link between theoretical conjectures and political-economic variables that serve as their proxies.

Econometric studies of the endogenous protection theory seek to explain the level of protection via two primary channels. On the one hand, protection levels are determined by macroeconomic variables, including real GDP, unemployment, inflation, and trade balance. Earlier studies following this approach include those of Magee (1987), Gardner and Kimbrough (1989), Bohara and Kaempfer (1991), Krol (1996), and Thornton and Molyneux (1997). They found evidence to suggest that macroeconomic factors affect the level of protection. On the other hand, many others have attempted to determine how particular characteristics of industries affect protection patterns. Empirical studies tend to demonstrate that a small number of firms, large employment size, and labor-intensive industries with high and rising import penetration are often related positively to higher protection (see Caves 1976; Baldwin 1985; and Trefler 1993). This paper falls squarely within the latter category. 
Thus far, existing empirical studies regarding the theory of endogenous protection have been conducted on a single-country basis, confined principally to the United States' experience, and limited to relatively modern times (post-war period). Empirical studies have utilized a host of different trade protection indicators, including nominal and effective tariffs, non-tariff coverage ratios, and exemptions from multinational trade liberalization (Rodrik 1995). In general, several hypotheses have been proposed in the literature to support the theory of endogenous protection, as described in the following section.

The interest group bypothesis, which is also referred to as the pressure group hypothesis, asserts that domestic interest groups exert their political influence over politicians in order to change trade policies that favor their interests. Olson (1965; 1983), Stigler (1971), and Pincus (1975) have argued that the influence of interest groups depends on the size of firms within the industry and the degree of concentration in terms of output and geography, the industry growth rate of output, the import penetration ratio, and the value-added share of output. Industry protection, for example, will be related negatively to the industry growth rates of output and will be related positively to the increase in the import penetration ratio (Gawande and Krishna 2003).

The adding machine hypothesis, first proposed by Caves (1976), emphasizes the importance of an industry's size in employment terms in achieving protection. According to this theory, politicians are likely to favor industries that employ large numbers of workers (i.e., voters) (Caves 1976; Baldwin 1985). Therefore, the numbers of employees in an industry positively affects the level of protection in that industry.

The status quo hypothesis is predicated on the 'conservative social welfare function' initiated by Corden (1974), which suggests that the government will support policies that prevent declines in real income for any significant group. The principal argument of this hypothesis is that politicians have a conservative respect for the status quo, and thus do not wish to incur large adjustment costs.

The comparative cost hypothesis suggests that industries that lose their comparative advantage and confront increased import competition are more likely to be given protection (Bhagwati 1982). In other words, industries with high export intensity and low import penetration will receive less protection.

The social change hypothesis is associated with the empirical studies of Ball (1967), Constantopoulos (1974), and Fieleke (1976). This hypothesis highlights government motivations, on social justice grounds, to promote an egalitarian pattern of income distribution in the economy by raising the living standard of the lowest income group. These authors hypothesize that protection levels will be higher in industries which more intensively utilize low-income, unskilled labor.

The hypotheses discussed above form several variables as determinants of tariff levels, including import penetration, export intensity, number of firms, number of workers, industry growth rate, etc. 
Baldwin (1985) draws three conclusions from this subject. First, high protection is likely to be associated with low wage and labor-intensive sectors, thereby implying that protection is utilized to help low-income groups. Second, protection levels positively impact industry employment levels, supporting the adding machine model. Third, protection is related negatively with the number of firms in the industry. This suggests that oligopolistic industries should find it easier than competitive industries to overcome the free rider problem by obtaining protectionist legislation.

Recently, as discussed by Gawande and Krishna (2003), the literature has moved in a 'structural' direction, linking more tightly empirical studies and the underlying theory. Noteworthy work in this new direction includes the studies of Findlay and Wellisz (1982), Feenstra and Bhagwati (1982), Mayer (1984), Hillman (1982; 1989), and Magee, Brock and Young (1989). Rodrik (1995) and Gawande and Krishna (2003) have also presented excellent comprehensive surveys of the theoretical and empirical literature regarding the endogeneity of trade protection. As put forth by Rodrik (1995), five approaches to modeling the endogenous protection theory have emerged from the literature-namely. median-voter, tariff-formation function, political support function, campaign contributions, and political contributions approaches.

The median-voter approach was initially introduced by Mayer (1984), and predicts that equilibrium trade policies will be biased against trade in capital-rich countries and will be in favor of trade in capital-poor countries. Levy (1997) utilized the median-voter approach to elucidate a mechanism whereby bilateral arrangements may undermine political support for a multilateral arrangement, but can never enhance political support for broader and freer trade. Dutt and Mitra (2002) used a cross-country dataset on inequality to corroborate the median-voter approach, which holds that an increase in inequality increases import protection in capital-abundant countries, but reduces trade barriers in capital-scarce countries.

The tariff-formation function approach was pioneered by Findlay and Wellisz (1982), who considered the tariff rate as the outcome of lobbying contests between opposing interest groups. Employing this approach, Bandyopadhyay, Lahiri, and Roy (2007) have evaluated the effects of political asymmetries in the formation of common external tariffs (CETs) in a customs union (CU). Their principal finding was that the CET rises monotonically with the degree of asymmetry in countries' influences if the two countries are equally susceptible to lobbying.

Hillman (1982) developed the political support function approach to explain why declining industries receive more protection. Under this approach, which is also referred to as the government's objective function, the government confronts a trade-off between the political support of consumers, on one hand, and support from capitalists, on the other. The support for the government from the industry increases in the industry's profits, whereas consumers raise their support when product prices decline (Eicher and Osang 2005). 
Long and Vousden (1991) extended Hillman's (1982) analysis to a general equilibrium Ricardo-Viner framework, and explained the manner in which this partial compensation outcome is influenced by the degree of risk aversion of the specific factor owners, as well as the manner in which the tariff revenues are redistributed. Brainard and Verdier (1997) have analyzed the adjustment path in declining industries under endogenous protection conditions. They determined that the level of tariffs is an increasing function of past tariffs. Additionally, when the costs of lobbying and adjustment are fully variable, declining industries contract more slowly over time, and never fully adjust.

The political contributions approach has been developed by Grossman and Helpman (1994). The work of Grossman and Helpman (G-H) provides an explicit structural framework within which organized interest groups influence politicians using political contributions. Goldberg and Maggi (1999), Mitra et al. (2002), and McCalman (2004) have applied this approach to the United States, Turkey, and Australia, respectively. They all concluded that the observed pattern of protection is consistent with the predictions of the G-H model.

The campaign contributions approach. which was advanced by Magee. Brock, and Young (1989), attempts to establish a direct link between campaign contributions, election outcomes, and policy choices. In this approach, lobbies make campaign contributions to increase the probability that their favored political party will win at the polls. For elegant analyses of these different approaches, see Rodrik (1995) and Gawande and Krishna (2003).

This paper extends the findings of earlier studies in several ways. First, no study thus far has attempted to apply the endogenous theory of tariffs to an explanation of tariff formation in developing countries (including Vietnam). Second, imports and trade protection are simultaneously modeled herein, using the two-stage least square estimator. Third, this study employs an up-to-date panel dataset that was only recently made available in Vietnam, allowing us to measure the dynamic interaction among trade flows, industry characteristics, and trade protection.

\section{THE MODEL}

The theory of endogenous protection asserts that higher import levels result in increased protection levels; these higher levels of protection, in turn, result in declines in imports. Therefore, the two effects may be isolable via the simultaneous estimation of a tariff equation and an import equation. This approach was first proposed by Trefler (1993) and was subsequently employed by Lee and Swagel (1997), Tombazos (2003), and Heo and Chung (2008). We witness that after more than two decades of economic reform, market disciplines have gradually dominated in the economic relations in Vietnam. The Vietnamese government 
has used tariffs as a policy tool to protect and upgrade its favored industries. In fact, to some extent, tariffs may bring about benefits to some protected industries against intensified competition resulting from market liberalization. In addition, tariffs would be seen as the outcomes of interest groups' lobbying efforts. It means that industries which are vulnerable to the market opening may lobby the government for preferences such as imposing tariffs and or other protectionist measures. Thus, we find that the theory of endogenous protection might fit the case of Vietnam. In order to assess tariffs and import penetration in Vietnam simultaneously, a system of two equations was adopted to enable simultaneous estimation via the two-stage least square method:

$$
\begin{aligned}
& T_{t t}=\alpha_{T}+\beta_{M /} M_{i t}+\delta_{7} X_{n}+\epsilon_{T} \\
& M_{\prime \prime}=\alpha_{M}+\beta_{T} T_{i t}+\delta_{M} X_{M t}+\epsilon_{M / t}
\end{aligned}
$$

where: $\alpha_{\%} \cdot \alpha_{3}$ : represents the vectors of the tariff and import constants, respectively; $\beta_{1}$. $\beta_{7}$ : represents the vectors of import penetration ratio and the tariff rate's coefficient, respectively; $\delta_{7} . \delta_{1}$ : represents the vectors of coefficients of industry characteristics of tariffs and import equations, respectively: $T_{t,}$ : represents the nominal average tariff rate in industry $i$ in year $t ; W_{i}$ : represents the import penetration ratio in industry $\mathrm{i}$ in year $\mathrm{t} ; X_{7}$ : represents vectors of industry characteristics that determine the trade protection level; $V_{11}$ : represents vectors of industry characteristics that determine import demand.

The import penetration enters the tariff equation in two ways. First, import penetration enters in a linear and direct fashion. Second, import penetration enters linearly but indirectly through $\perp$ (import penetration) since $\perp$ (import penetration) equals $M_{i, 1}-M_{t, 11}$, where $M_{i \prime 1}$ is the import penetration in industry $\mathrm{i}$ in year $\mathrm{t}$.

In accordance with the studies conducted by Ray (1981), Trefler (1993), Tombazos (2003), and Heo and Chung (2008), we incorporated into the dependent variables a set of relevant political-economic factors that were expected to affect the level of protection and imports across industries.

\section{Tariff Equation}

The unweighted nominal average tariff rate, which serves as a measure of trade protection, was employed as the dependent variable in the tariff equation. These tariff rates correspond to the two-digit ISIC level during the 2001-2006 period. In this study, NTBs were excluded, as they are extremely difficult to quantify and compare over time.

Insofar as the regressors of the tariff equation are concerned, the endogenous protection theory asserts that the equilibrium level of trade protection represents 
the outcome of the interaction between supply and demand factors. That is, the protection level is demanded by interest groups that rationally calculate their costs and benefits of lobbying for protection, and is supplied by politicians who seek to maximize their own self-interested objectives (Trefler 1993). Therefore, we include a number of political-economic variables at the right-hand-side of the tariff equation, in an effort to take into consideration the measures of the costs and benefits of lobbying by interest groups, and of the supply of protection by politicians. These include import penetration as well as its change over time, export intensity, number of establishments, industry growth, employment size, and capital stock. The list of regressors is provided in Table 1, along with the methods employed for derivation.

The inclusion of the import penetration ratio variable is motivated by the interest group hypothesis of tariff determination, which holds that the degree of import penetration varies directly with the degree to which the affected industry lobbies governments for protection. The import penetration ratio, which is measured as imports relative to domestic demand, is used rather than the unscaled imports to capture the extent to which the infiltration of foreign products into the domestic economy poses a legitimate threat to domestic producers (Tombazos 2003). As a consequence, a variety of empirical studies have incorporated this variable into their model specifications. The theoretical framework of the theory of endogenous protection indicates that industry protection is related positively to the increase in the import penetration ratio.

Tabie 1. Descriptions of Variabi.fs Used in the Regression analysis

\begin{tabular}{ll}
\hline \multicolumn{1}{c}{ Tariff Equation } & \multicolumn{1}{c}{ Regressor } \\
\hline Import Penetration & Imports as a percentage of domestic demand \\
$\Delta$ (Import penctration) & Change in import penetration \\
Export intensity & Exports as a percentage of turnover \\
Establishments & Number of firms scaled by industry turnover \\
Industry growth & Change in turnover over the previous year \\
Employment & Unscaled number of workers in industry \\
Capital stock & Value of total industry assets \\
\hline Import Equation & Regressor \\
Tariff & Nominal average tariff rate \\
Capital intensity & Value of total assets scaled by turnover \\
Labor intensity & Gross wages and salaries scaled by turnover \\
\hline
\end{tabular}

However, the empirical evidence regarding the relationship between trade protection and import penetration is somewhat ambiguous. Some studies have detected 
a positive and statistically significant coefficient of import penetration on trade protection (Lee and Swagel 1997; Tombazos 2003), whereas others have reported a positive but statistically insignificant relationship (Trefler 1993; Heo and Chung 2008). On the other hand, Grossman and Helpman (1994), in their paper "Protection for Sale," argue that the relationship between import penetration and the level of protection differs between the organized and unorganized sectors. In their model, organized sectors with lower import penetration will receive more protection, whereas unorganized sectors with higher levels of import penetration will also receive greater protection. Chang (2005) argues further that, under monopolistic competition conditions, a sector with lower import penetration will receive a higher degree of import protection, regardless of whether or not the sector is politically organized. Goldberg and Maggi (1999), who have tested the G-H model using cross-industry data on the U.S. NTB coverage ratios, have detected a negative linkage between import penetration and trade protection, but this is not statistically significant within the group of organized sectors. Other studies, including those of Anderson (1980) and Aislabie (1988), also find import penetration to be negatively related with the level of protection.

For reasons discussed in previous studies, such as those of Baldwin (1985). Tombazos (2003), and Heo and Chung (2008), among others, changes in import penetration ( $\Delta$ import penetration) are also included in the tariff equation to control for declining sectors (those with large increases in import penetration). Declining sectors are likely to receive more protection so as to reduce adjustment costs. Therefore, this variable quantifies the degree of intensification of import competition at the industry level. Hence, the coefficient associated with this variable is anticipated to be positive.

The level of protection is expected to be correlated negatively with the share of exports relative to the industry's revenue. An export-oriented industry also generally does not require protection, as it represents the sector's comparative advantage or because, with intra-industry trade, protection will provoke a retaliatory response abroad.

According to Stigler (1971), Baldwin (1985), and Trefler (1993), among others, the number of firms in an industry is also thought to perform a function in determining a country's protection level. A smaller number of firms have alleviated the free-rider problem in coordinating a lobby, thus reducing transaction costs and increasing the protection level. As a smaller number of firms in an industry is reflective of a higher probability of effective coordination, according to the interest group bypothesis, the level of protection in an industry should therefore be related negatively with the number of firms. This variable enters the tariff equation using the number of establishments scaled by turnover.

Along with the large number of empirical findings showing that the protection level of an industry responds positively to the industry's employment level, the impact of employment size measured by the unscaled number of workers in 
the industry is also assessed in the tariff equation (Baldwin 1985; Tombazos 2003). The finding that employment levels are related positively to the level of industry employment is consistent with the adding machine hypothesis.

Olson (1983) argued that organized interest groups may be more likely to exert their political influence when confronting a changing economic environment that threatens their income and jobs. Additionally, both Hillman (1982) and Trefier (1993) have argued that an industry is thought to be disadvantaged if it experiences a slow growth rate, and that such industries tend to receive a greater degree of protection (Hillman 1982; Long and Vousden 1991). Therefore, it has been argued that industry protection responds negatively to industry growth rates in output.

Capital stock is utilized in the present study to show two distinct features corresponding to the trade protection level. If entry barriers, for which capital stock is used as a proxy, apply to both domestic and foreign rivals, then the barriers obviate the need for protection, thereby reducing the level of protection. On the other hand, if the barriers apply only for domestic entry, then the barriers increase the level of protection (as a method of excluding foreign rivals) (Trefler 1993). Accordingly, it can be asserted that capital mobility is inversely related with the quasi-rents associated with protection, and thus directly related with the profitability of lobbying efforts.

\section{Import Equation}

In constructing the independent variables for import equation, Trefler (1993) has argued that the equation must fulfill two criteria. First, it must be able to predict the pattern of trade. Second, it must be compatible with the theory of endogenous protection. In this context, the import equation in this study was formulated with an eye toward consistency with a Heckscher-Ohlin model. Specifically, the present equation is based on the tariff levels and factor intensities of capital and labor. Considering that these variables differ from the exogenous variables used in the tariff equation, the import equation is identified econometrically.

In the import equation, the tariff rate is expected to be correlated negatively with import penetration, as a high tariff level should result in a reduction in the import penetration ratio. Alternatively, as tariffs decline, import penetration is expected to rise.

Capital intensity is represented by the ratio of the value of total assets over industry's turnover. The labor intensity is assessed by the sum of gross wages and salaries scaled by turnover. The capital intensity is related positively to import penetration in cases in which the country's imports are capital-intensive, reflecting the comparative disadvantage of that country in terms of capital-intensive products (Ray 1981). The labor intensity is expected to be negatively related 
to import penetration if that country possesses a comparative advantage in labor-intensive products. To the extent that Vietnam might be expected to hold a comparative disadvantage in the production of capital-intensive products and a comparative advantage in labor-intensive products, the capital intensity should be correlated positively with the import penetration ratio, whereas the labor intensity should be expected to be related negatively to imports.

\section{Estimation Method and Data}

Trefler's study (1993) is worth mentioning in that it takes into consideration the inter-relationship between imports and trade protection. His principal argument is that a two-way dependence exists between imports and protection: to wit, an increase in imports stimulates demands for protection, whereas an increase in protection naturally restricts imports. According to Trefler, unless imports and protection were modeled as simultancously determined endogenous variables, estimates of the impact of trade libcralization on imports would tend to exhibit a downward bias. In an effort to eliminate simultaneity bias between import penetration and tariffs, a two-stage least square (2SLS) method was employed.

A panel dataset on trade and manufacturing industries at the two-digit ISIC level during the period from 2001-2006 was employed in this study. Data on industry exports and imports were extracted from the United Nations Statistics Division Commodity Trade Database (UN COMTRADE). The unweighted nominal average tariff rate was obtained from the United Nations Conference on Trade and Development Trade Analysis Information System (UN TRAINS). Data on establishments and employment size were acquired from the Statistical Yearbooks of Vietnam (GSO 2009). Data on wages and salaries, turnover, and total assets were taken from the Enterprise Survey (GSO 2008). Since the survey was carried out to document the data up to year 2006, our dataset was allowed to be compiled to cover only the period from 2001-2006. In an effort to convert economic data from the Vietnamese Dong into the U.S. dollar, we used the nominal exchange rates (annual average) reported by the International Monetary Fund, which were published in its series of Vietnam Statistical Appendices for 2006 and 2007 (IMF 2006 and 2007).

Table 2 reports summary statistics on the data employed in the study. As indicated in Table 1, all variables except for employment and capital stock are denoted in relative figures. Employment is measured in thousand persons and capital stock is denoted in million US\$. The summary statistics show that there exist big gaps among industries in terms of capital stock, employment and the tariffs imposed on them. The lowest tariff was 2.47 percent whereas the highest tariff reached 65 percent. Therefore, it is interesting to study how particular characteristics of industries affect protection patterns in Vietnam. 
Table 2. Expected Signs and Descriptive Statistics

\begin{tabular}{|c|c|c|c|c|c|c|}
\hline \multirow{2}{*}{ Industrial characteristics } & \multirow{2}{*}{ Hypothesis } & \multirow{2}{*}{$\begin{array}{l}\text { Expected } \\
\text { sign }\end{array}$} & \multicolumn{4}{|c|}{ Descriptive Statistics } \\
\hline & & & Obs. & Mean & Min. & Max. \\
\hline Import penetration ratio & Interest group & +1 & 132 & 0.54 & 0.04 & 1.31 \\
\hline$\Delta$ (Import penctration) & Interest group/status quo & + & 132 & -0.03 & -2.61 & 0.51 \\
\hline Establishments & Interest group & - & 132 & 0.60 & 0.01 & 3.03 \\
\hline Exports & Interest group & + & 132 & 0.48 & 0.03 & 2.71 \\
\hline Employment & Adding machine & + & 132 & 120.82 & 0.83 & 585.41 \\
\hline Industry growth & Interest group/status quo & - & 132 & 0.26 & -0.35 & 0.82 \\
\hline Capital Stock & Barriers to entry & $+1-$ & 132 & 708.30 & 28.89 & 3885.69 \\
\hline Tariff & & - & 132 & 20.20 & 2.47 & 65.00 \\
\hline Capital intensity & & + & 132 & 0.43 & 0.12 & 1.38 \\
\hline Labor intensity & & - & 132 & 2.84 & 0.10 & 38.19 \\
\hline
\end{tabular}

\section{EMPIRICAL RESULTS AND DISCUSSIONS}

The estimated coefficients of tariffs and import equations using 2001-2006 data are both reported in Table 3, along with the t-statistics and adjusted R-square values. All estimated coefficients evidenced the expected sign, with the exception of the import penetration ratio and its changes. The explanatory power of the political variables was relatively high in relation to other studies, explaining more than 41 percent of the variation in Vietnam's tariff rates. We note that these results were generally well-reconcilable with endogenous protection theory.

The estimated coefficient on import penetration is negative but statistically insignificant, indicating that import penetration exerts no discernible impact on Vietnamese tariff rates. This result is counter to what was noted in previous empirical studies, which have typically found a positive relationship to exist between protection and import penetration (Trefler 1993; Lee and Swagel 1997). However, there are several explanations for this unexpected sign. Both Goldberg and Maggi (1999) and McCalman (2004) have explained this negative sign to indicate that the domestic output is related directly with the degree to which the owners of the specific factors gain from an increase in the domestic price, whereas the volume of imports is related directly with the degree to which the economy loses as the result of protection. Grossman and Helpman provide another explanation $(1994,849)$, noting that "the most serious political opposition to protection arises when higher prices stand to harm other producer interests. The users of intermediate inputs often are as politically active against import barriers as are the domestic manufacturers who favor such protection." It is 
crucial to note that Vietnamese imports of intermediate goods increased significantly during the $1999-2005$ period, from 42.3 percent to 62.5 percent (Table 4). Therefore, this negative result reflects the fact that the political process tends to favor the interests of intermediate producers relative to those of final-goods producers, at least in the case of Vietnam. Grossman and Helpman (1994) have also concluded that organized sectors with lower import penetration will tend to receive greater amounts of protection. This is particularly true in the case of Vietnam. The average data over the study period demonstrates that industries with low import penetration ratios (less than 0.55 ) frequently face high tariff rates (more than 20 percent)-this is the case with products such as tobacco ( 65 percent), food products and beverages ( 31.47 percent), apparel (47.62 percent), and the assembly and repair of motor vehicles ( 33.77 percent) (see Appendix 1).

Table 3. Regression Result for the Simultaneous Equation, 2001-2006

\begin{tabular}{|c|c|c|}
\hline \multirow{2}{*}{ Variable } & \multicolumn{2}{|c|}{2 SIS } \\
\hline & Cuefficient & t-statistic \\
\hline \multicolumn{3}{|l|}{ Tariff Equation } \\
\hline Exports & -4.5748 & -0.960 \\
\hline Establishment & -5.4946 & $-2.820^{* *}$ \\
\hline Employment & 0.0499 & 4.020 \\
\hline Import Penctration & -12.4965 & -1.130 \\
\hline$د$ (import penetration) & -8.1064 & $-1.750^{\circ}$ \\
\hline Industry Growth & .8 .6573 & -1.500 \\
\hline Capital Stock & -0.0052 & $-2.740^{* \cdots}$ \\
\hline Constant & 32.0135 & $5.020^{* *}$ \\
\hline Adjusted $R$-square & 0.4107 & \\
\hline \multicolumn{3}{|l|}{ Import Equation } \\
\hline Tariff rate & -0.016 & $-4.850^{\ldots+\cdots}$ \\
\hline Capital Intensity & -0.198 & $-1.860^{\circ}$ \\
\hline Labor Intensity & 0.012 & $2.850^{* *}$ \\
\hline Constant & 0.906 & $9.050^{* * *}$ \\
\hline No. of observation & 132 & \\
\hline Adjusted $R$-square & 0.3166 & \\
\hline
\end{tabular}

NOTE: ", and represent statistical significance at the 1 percent, 5 percent, and 10 percent level, respectively.

An alternative explanation for the negative relationship between import penetration and tariff rates was provided by Anderson $(1980,139)$ who argued that 
"the more assisted industries have not necessarily been those whose domestic markets have been supplied largely by imports. But this is probably because industry assistance itself has reduced import penetration ratios in highly assisted industries to well below what they would have been in the absence of assistance."

The estimated coefficient of change in import penetration [ $\Delta$ (import penetration)] is also negative, and is statistically significant at a level of 10 percent. This means that the change in import penetration is correlated negatively with the import's tariff rates, thereby implying that despite the short-run intensification of import competition, it does not necessarily result in a higher level of protection. Even though this result is not consistent with the majority of earlier studies, there are at least two cases-studies of Australia and South Korea-in which the empirical results were identical to those of this study (see, Tombazos 2003; Heo and Chung 2008). Tombazos (2003) explained this phenomenon by asserting that the results may reflect the presence of certain rigidities in the system that may derive from the increasingly unpalatable nature of tariffs. The rise of imports as a percentage of domestic consumption in industries that traditionally received only a moderate level of protection may cause relatively small changes in the protection level, whereas industries with a long tradition of receiving considerable governmental assistance may already enjoy a higher relative level of protection.

As suggested in the earlier discussion, the estimated coefficient on export intensity has the expected negative sign, meaning that export intensity negatively influences the tariff rates applied. The increase in export intensity thereby reduces industry groups lobbying efforts for government protection. Additionally, this is consistent with the notion that countries tend to refrain from protecting industries whose exports are important, for fear that their trading partners may retaliate against any import restraints (Lee and Swagel 1997). However, the estimated coefficient in the present study was not statistically significant, although it was statistically significant in studies of the United States and Australia (Trefler 1993; Tombazos 2003). The results of the investigation of Vietnam's manufacturing industries reveal that the two industries with the highest export intensity ratios face average tariff rates of less than $6 \%$ (petroleum and office, accounting, and computing machinery).

As far as the estimated coefficient of the establishments is concerned, the regression results shows robust evidence that the number of establishments is correlated statistically significantly, and negatively, with the applied tariff rate. This finding is consistent with both the theoretical prediction of the interest group hypothesis and other previous findings (e.g., Baldwin 1985; Heo and Chung 2008). Thus, this result confirms that a smaller number of establishments, relative to industry turnover, alleviate the free-rider problem, thereby resulting in an increase in the protection level. In Vietnam, industries with a small number of firms (scaled by industry turnover) that are protected by high tariff rates 
include tobacco, leather, wearing apparel, textiles, the assembly and repair of motor vehicles, and radio and communication equipment (see Appendix 1).

The regression result for the employment size variable is positive, with a high degree of statistical significance. The significant positive coefficient on the employment variable is therefore consistent with the adding machine hypothesis, which holds that those industries that comprise a large number of workers should receive a greater degree of protection. This means that industries characterized by large employment size should be provided with higher levels of protection, as the politicians require the votes of the employees and their relatives in order to maximize the probability of reelection. This result is consistent with earlier findings, most notably Baldwin's study (1985). Which industries enjoy high tariff protection owing to their high employment rate in Vietnam? During the 2001-2006 period, seven industries had a total employment rate of more than 100,000 workers coupled with high tariff rates: wearing apparel (47.62 percent); textiles ( 32.48 percent); food products and beverages ( 31.47 percent); leather (29.35 percent); furniture ( 24.11 percent), non-metallic mineral products ( 21.65 percent); and fabricated metal products (17.57 percent) (see Appendix 1).

Additionally, the government tends to protect those industries with low industry growth rates. The estimated coefficient is related negatively with the level of protection, but this correlation is not statistically significant. This result thus may bolster, to some degree, the interest group hypothesis, which holds that industry protection is correlated negatively with the industry growth rate. Therefore, in this case, the slower the growth of the industry, the more the industry will lobby for a higher common external tariff. This result is consistent with the findings of earlier empirical studies, such as that of Heo and Chung (2008).

Finally, the negative and highly significant coefficient on the capital stock demonstrates that barriers to entry eliminate the need for protection. This result is consistent with the role of capital stock as a proxy for existing barriers to entry that diminish the value and, therefore, the level of protection (Tombazos 2003). This result is consistent with the findings of other studies (Trefler 1993; Tombazos 2003). In conclusion, with the exception of the coefficient of import penetration and changes in import penetration, other variables-namely export intensity, number of firms, industry growch, and employment size-are all consistent with our a priori expectations.

Turning our attention to the import equation, then, it is worth noting that the tariff rates applied exerted the predicted highly significant negative influence on import penetration. Therefore, it appears that tariff rates, at least in the case of Vietnam, have substantially restricted imports.

Counter to our expectations, the estimated coefficient of capital intensity was found to be significantly negatively correlated with import penetration, whereas 
the coefficient of labor intensity was related positively and significantly with import penetration. This means that Vietnam's manufacturing imports accelerate in industries with higher labor intensity ratios, but decelerate in industries with lower capital intensity ratios.

Do these results reflect a comparative advantage of Vietnam in terms of capital-intensive products? To determine this, we calculated the revealed comparative advantage indices for different manufacturing sectors to assess Vietnam's comparative advantage sectors. The results of those calculations demonstrated that industries with high capital-intensity ratios do not necessarily enjoy sizeable comparative advantages.

Table 4. Vietnam's Direction of Trade by Stage of Production, 1999-2005

\begin{tabular}{|c|c|c|c|c|c|c|}
\hline \multirow{2}{*}{ Product Category } & \multicolumn{3}{|c|}{ Exports } & \multicolumn{3}{|c|}{ Imports } \\
\hline & 1999 & 2002 & 2005 & 1999 & 2002 & 2005 \\
\hline Primary goods & 69.13 & 25.88 & 30.86 & 5.06 & 4.57 & 5.19 \\
\hline Intermediate goods & 17.55 & 11.61 & 12.64 & 42.31 & 57.86 & 62.52 \\
\hline Semi-finished guods & 0.70 & 8.89 & 9.35 & 18.37 & 52.63 & 54.99 \\
\hline Parts and Components & 16.8 .4 & 2.72 & 3.29 & 23.94 & 5.23 & 7.53 \\
\hline Final goods & 8.39 & 61.37 & 56.04 & 48.74 & 36.34 & 31.81 \\
\hline Capital goods & 2.85 & 2.75 & 4.04 & 27.42 & 21.94 & 20.16 \\
\hline Consumption goods & 5.54 & 58.61 & 52.00 & 21.32 & 14.40 & 11.65 \\
\hline Others & 4.93 & 1.14 & 0.46 & 3.90 & 1.23 & 0.47 \\
\hline Total & 100 & 100 & 100 & 100 & 100 & 100 \\
\hline
\end{tabular}

SOURCE: Author's calculation based on COMTRADE.

With the exception of the textile and furniture sectors, all other high capital-intensive sectors (capital intensity ratio of over 0.4 ) evidence a comparative disadvantage (the value of the RCA index is less than one). On the other hand, low capital-intensive sectors, including leather goods, apparel, food and beverages, and tobacco, generally show evidence of comparative advantage. Therefore, the negative significant effect of capital intensity on import penetration does not mean simply that Vietnam has a comparative advantage in capital-intensive products. Rather, this result may reflect the fact that Vietnam has reduced its imports of capital products in recent years. This is consistent with the data shown in Table 4, which indicates that the imports of capital goods declined to 20.16 percent in 2005 from 27.42 percent in 1999 . Over the same period, Vietnam's exports of capital goods increased from 2.85 percent to 4.04 percent. With regard to labor intensity, this result may reflect the fact that Vietnam not only exports, but also imports, labor-intensive products. 


\section{CONCLUSION}

Using a simultaneous equation model of tariffs and imports, this paper empirically evaluates the factors determining tariff rates in Vietnam, using two-digit ISIC level data from 2001 to 2006 . The major findings of the present study can be summarized as follows:

First, the regression results show robust evidence that market concentration is related positively with the tariff rate, and this result is statistically significant. This finding confirms that a smaller number of firms, relative to industry turnover, alleviate the free-rider problem, thereby resulting in an increase in the level of protection.

Second, the regression results for the employment size variable are highly statistically significantly positive, which supports the adding machine hypothesis. Due to political considerations, a higher level of protection was provided to industries with large numbers of workers.

Third, the estimated coefficient on import penetration was negative, but statistically insignificant, indicating that import penetration has no discernible impact on Vietnamese tariff rates. However, the estimated coefficient of the change in import penetration is also negative, and is statistically significant at a level of $10 \%$. This implies that, despite the intensification of import competition in the short-run, such changes do not necessarily bring about a higher level of protection.

Fourth, exports exerted a negative influence over all applied tariff rates. The increase in the export ratio thus reduces industry groups' lobbying efforts for government protection, although the estimated coefficient in the present study was not statistically significant.

Fifth, the government tends to protect low-growth industries, although the estimated coefficient is statistically insignificant. This result, therefore, may lend some support to the interest group hypothesis: the slower the growth of the industry is, the more the industry lobbies for a higher common external tariff. Finally, the negative and highly significant coefficient of the capital stock shows that, by controlling the entry of both domestic and foreign rivals, barriers to entry can eliminate the need for protection.

In general, the findings of this study provide further evidence favoring the endogenous trade theory. This case study of Vietnam may, therefore, greatly contribute to our current understanding of the political economy of protection in developing countries.

\section{REFERENCES}

Anderson, Kim. 1980. The Political Market for Government Assistance to Austra- 
lian Manufacturing Industries. Economic Record 56(153): 132-44.

Bandyopadhyay, Subhayu, Sajal Lahiri, and Suryadipta Roy. 2007. Political Asymmetry and Common External Tariff in a Customs Union. FRB of St. Louis Working Paper No. 2007-038A, Missouri: Federal Reserve Bank of St Louis.

Ball, David S. 1967. United States Effective Tariffs and Labor's Share. Journal of Political Economy 75(2): 183-87.

Baldwin, Robert E. 1985. The Political Economy of U.S. Import Policy. Cambridge, MA: MIT Press.

Bhagwati, Jagdish N. 1982. Shifting Comparative Advantage, Protectionist Demands, and Policy Response. in Jagdish N. Bhagwati (ed.) Import Competition and Response. Chicago: University of Chicago Press.

Brainard, Lael, and Thierry Verdier. 1997. The Political Economy of Declining Industries: Senescent Industry Collapse Revisited. Joumal of International Economics 42(2): 221-37.

Brock, William P., and Stephen P. Magee. 1978. The Economics of Special Interest Politics: The Case of Tariffs. American Economic Retiew 68(2): 246-50.

Bohara, Alok K., and William H. Katempfer. 1991. A Test of Tariff Endogeneity in the United States. The Amerian Economic Reziew 81(4): 952-60.

Caves, Richard E. 1976. Economic Models of Political Choice: Canada's Tariff Structure. Canadian Journal of Economics 9(2): 278-300.

Chang. Pao-Li. 2005. Protection for Sale under Monopolistic Competition. Jounal of International Economics 66(2): 509-26.

Constantopoulos, Maria. 1974. Labor Protection in Western Europe. European Economic Review 5(4): 313-28.

Corden, W. Max. 1974. Trade Policy and Economic Welfatr. Oxford: Oxford University Press.

Dutt, Pushan and Devashish Mitra, 2002. Endogenous Trade Policy through Majority Voting: An Empirical Investigation. Journal of International Economics 58(1): 107-34.

Eicher, Theo, and Thomas Osang. 2005. Political Support or Contributions: An Empirical Investigation of US Trade Policy. in Guenter Heiduk and Kar-yiu Wong (eds.), WTO and World Trade: Challenges in a New Era. Berlin: Springer Verlag.

Feenstra, Robert C. and Jagdish N. Bhagwati. 1982. Tariff Seeking and the Efficient Tariff. in Jagdish N. Bhagwati, (ed.). Import Competition and Response. Chicago: University of Chicago Press.

Fieleke, Norman. 1976. The Tariff Structure for Manufacturing Industries in the United States: A Test of Some Traditional Explanations. Columbia Journal of World Business 11: 98-104.

Findlay, Ronald and Stanislaw Wellisz. 1982. Endogenous Tariffs, the Political Economy of Trade Restrictions and Welfare. in Jagdish N. Bhagwati, (ed.). 
Import Competition and Response. Chicago: University of Chicago Press. Gawande, Kishore and Pravin Krishna. 2003. The Political Economy of Trade Policy: Empirical Approaches, in James Harrigan and Eun K. Choi, (eds.), The Handbook of International Trade. Oxford: Blackwell.

Gardner, Grant W. and Kent Kimbrough. 1989. The Behavior of U.S. Tariff Rates. American Economic Review 79(1): 211-18.

General Statistics Office (GSO). 2008. The Real Situation of Enterprises through the Results of Surveys. Hanoi: Statistical Publishing House. 2009. Statistical Yearbook of Vietnam. Hanoi: Statistical Publishing House.

Goldberg, Penclopi, and Giovanni Maggi. 1999. Protection for Sale: An Empirical Investigation. American Economic Review 89(5): 1135-55.

Grossman, Gene, and Elhanan Helpman. 1994. Protection for Sale. American Economic Retiew 84(4): 8.33-50.

Helleiner, G. K. 1977. The Political Economy of Canada's Tariff Structure: An Alternative Model. Canadian Journal of Economics 4(2): 318-26.

Heo, Yoon, and Yuric Chung. 2008. The Endogeneity of Tarifts in Korea. Journal of International Economic Studies 22: 113-22.

Hillman, Arye L. 1982. Declining Industries and Political Support Protectionist Motives. American Ecammic Retiew 72(5): 1180-87.

1989. The Political Economy of Protection. Chur: Harwood Academic Publishers.

International Monetary Fund (IMF), 2007. Vietmam: Statistical Appendix: IMF Country Report No. 07/386, Washington, D.C: International Monetary Fund. 2006. Vietnam: Statistical Appendix. IMF Country Report No. 06/52.

Washington, D.C.: International Monetary Fund.

Krol, Robert. 1996. Testing Tariff Endogeneity in Japan: An Comparison of Pre- and Post-War Periods. Economic Letters 50(3): 399-406.

Lee, Jong-Wha and Philip Swagel. 1997. Trade Barriers and Trade Flows Across Countries and Industries. Retieu of Economics and Statistics 79(3): 372-82.

Levy, Philip. 1997. A Political-Economic Analysis of Free Trade Agreements. American Economic Review 87(4): 506-19.

Long, Ngo V. and Neil Vousden. 1991. Protectionist Responses and Declining Industries. Journal of International Economics 30, no.1-2: 87-103.

Magee, Stephen. 1987. Endogenous Policy Theory: The Political Economy of U.S. Protection. in Herbert Giersch, (ed.), Free Trade and the World Economy: Towards an Opening of Markets. Tubingen: Mohr.

Magee, Stephen, William Brock, and Leslie Young. 1989. Black Hole Tariffs and Endogenous Policy Theory. Cambridge and New York: Cambridge University Press.

Mayer, Wolfgang. 1984. Endogenous Tariff Formation. American Economic Review 74(5): $970-85$. 
McCalman, Philip. 2004. Protection for Sale and Trade Liberalization: An Empirical Investigation. Review of International Economics 12(1): 81-94.

Mitra, Devashish. 1999. Endogenous Lobby Formation and Endogenous Protection: A Long Run Model of Trade Policy Determination. American Economic Review 89(5): 1116-34.

Mitra, Devashish, Dimitrios Thomakos, and Mehmet Ulubasoglu. 2002. Protection For Sale in a Developing Country: Democracy Versus Diclatorship. Review of Economics and Statistics 84(3): 497-508.

Olarreaga, Marcelo and Isidro Soloaga. 1998. Endogenous Tariff Formation: The Case of Mercosur. The World Bank Economic Review 11(2): 297-320.

Olson, Mancur. 1965. The Logic of Collective Action: Public Goods and the Theory of Groups. Cambridge: Harvard University Press.

1983. The Political Economy of Comparative Growth Rates, in Mueller, Dennis (ed.), The Political Economy of Grouth, New Haven. CT: Yale University Press.

Peltzman, Sam. 1976. Towards a More General Theory of Regulation. Journal of Law and Economics 19(2): 211-48.

Pincus, J. J. 1975. Pressure Groups and the Pattern of Tariffs. Journal of Political Economy 83(4): 757-78.

Ray, Edward. 1981. "Tariff and Nontariff Barriers to Trade in the United States and Abroad." Review of Economics and Statistics 63(2): 161-8.

Rodrik, Dani. 1995. Political Economy of Trade Policy. in Grossman, G., Rogoff, K. (eds.), Handbook of International Econumics 3: 1457-94.

Stigler, George J. 1971. The Theory of Economic Regulation. Bell Journal of Economics and Management Science 2: 2-21.

Thornton, John and Philip Molyneux. 1997. Tariff Endogeneity: Evidence from $19^{\text {th }}$ Century Europe. Economic Letters 56(3): 345-50.

Tombazos, Christis G. 2003. Unprotective Tariffs, Ineffective Liberalization, and other Mysteries: An Investigation of the Endogenous Dimension of Trade Policy Formation in Australia. Southern Economic Journal 70(1): 49-74.

Trefler, Daniel. 1993. Trade Liberalization and the Theory of Endogenous Protection: An Econometric Study of U.S. Import Policy. Joumal of Political Economy 101(1): 138-60.

UN COMTRADE, United Nations Statistics Division. United Nations Commodity Trade Statistics Database. http://comtrade.un.org/db/default.aspx.

UN TRAINS, United Nations Conference on Trade and Development. Trade Analysis and Information System. http://rO.unctad.org/trainsnew/index.shtm. 


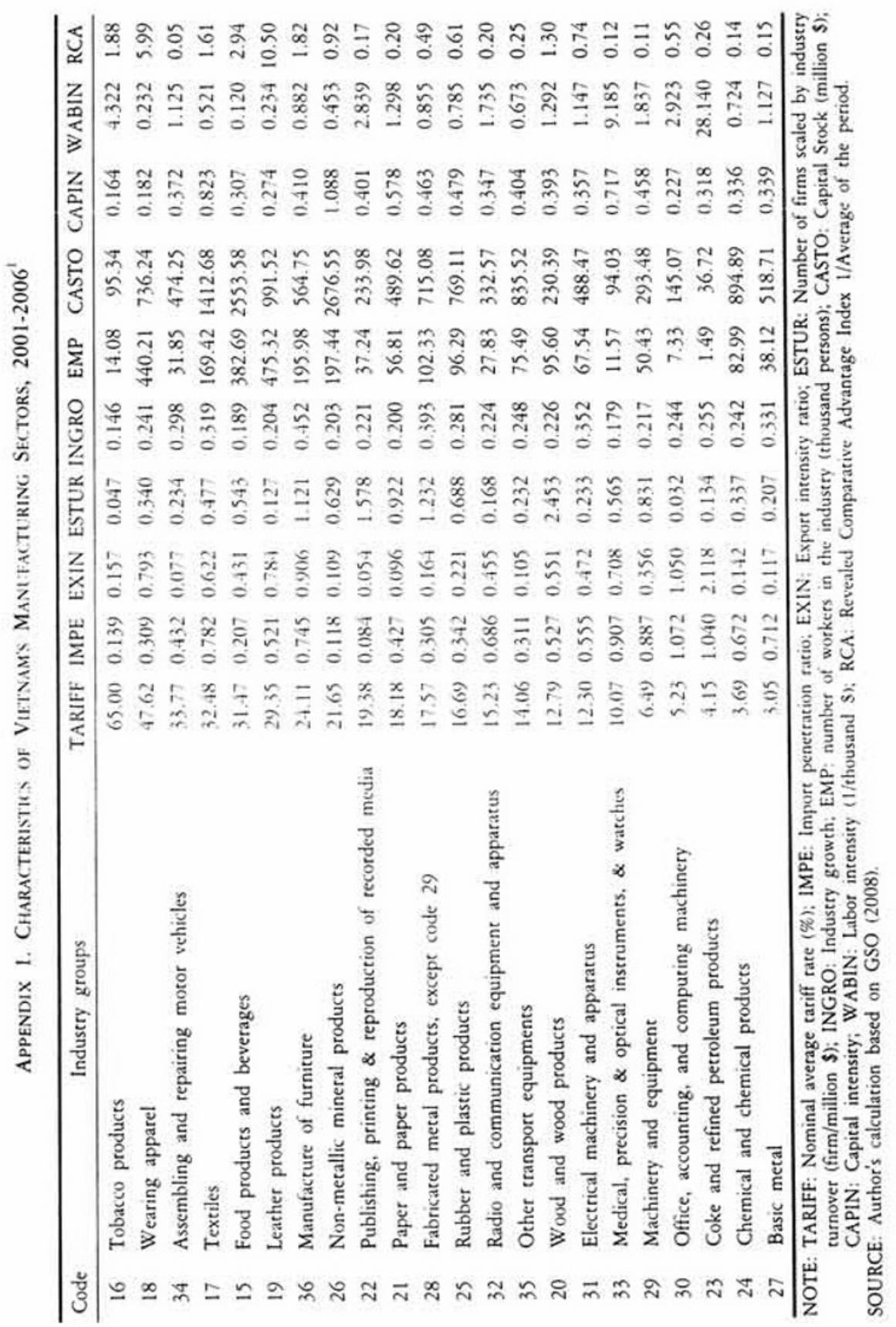

